\title{
Multilingual pedagogies in practice
}

\section{Mei French \\ University of South Australia}

Abstract: Amongst Australian EAL specialists there is increasing recognition of the value of incorporating students' home languages and cultural knowledge into teaching and learning. However there remains a need for guiding principles for developing effective multilingual and translanguaging approaches for linguistically diverse students. This paper presents some classroom approaches and suggest principles for effective multilingual curriculum and pedagogy. An ethnographic study in an Australian high school revealed that students used their multilingual repertoires to support learning individually, collaboratively and through access to external information. Teachers responded by rejecting, accepting or actively engaging students' multilingual resources. Analysis of teaching approaches suggests some principles for effective multilingual classroom practice. Successful multilingual pedagogies require both teachers and students to challenge the "monolingual mindset" (Clyne, 2008, p. 347) of Australian education. Attention to both vertical and horizontal dimensions of multilingualism (Heugh, 2018) is also crucial. Additional principles include affirming multilingualism, attending to affect, developing shared learning outcomes, defining a social purpose and addressing practical considerations. A key to success is that these pedagogies are developed from students' existing multilingual practices. It is hoped that proposing these principles can extend discussion and research around the use of multilingual resources in school-based learning.

Key words: multilingual pedagogies, multilingualism, translanguaging, English language learners, EAL, secondary school

\section{Introduction}

A common observation in Australian education is that linguistic and cultural diversity amongst students is increasing. These observations often foreground concerns about challenges for language learning and academic achievement, particularly in the context of a "monolingual mindset" (Clyne, 2008, p. 347) which privileges monolingual constructions of language, and 
particularly English, in educational policy and practice. However, an alternative perspective is available, in which students' languages are viewed as resources for learning, and diversity an opportunity for enlivening curriculum and pedagogy.

Research in an Australian high school suggests that within a monolingually oriented system, there are still actions that teachers and students can take to implement a multilingual approach to learning, particularly within English as an Additional Language (EAL) classrooms. This paper describes examples of multilingual approaches and proposes some principles for effective multilingual pedagogies, to support teachers to further develop this practice in their classrooms.

\section{Multilingualism in learning}

Particular understandings of language and multilingualism underpin a multilingual stance towards education (Ollerhead, Choi, \& French, 2018). Multilingualism is understood as a single, complex and dynamic "multilingual repertoire" (Busch, 2012) comprised of multiple languages and other multilingual resources including extensive expertise in some languages, knowledge of other languages, sociolinguistic skills, metalinguistic processes, and knowledge learnt through a range of languages (Cummins, 2009; Saxena \& Martin-Jones, 2013). This is in contrast to the "two solitudes" assumption (Cummins, 2008, p. 65) in which languages are seen as separate bodies of knowledge bounded by rigid rules.

As an application of multilingual repertoires, translanguaging is attracting interest in education. In simple terms, translanguaging can be understood as cognitive or communicative linguistic practice that combines features of multiple languages, including translating, code-switching (see García, 2009; Slembrouck \& Rosiers, 2018, p. 168), code-mixing or meshing, and hybrid languages.

Understanding horizontal and vertical dimensions of multilingualism (Heugh, 2015, 2019) is also important for multilingual education. In horizontal multilingual practice, speakers draw from their entire repertoire to engage shared linguistic resources and negotiate meaning (Heugh, 2015, 2019). The vertical dimension represents hierarchical linguistic structures which, as May (2011) identifies, allow participation in discourses of power. Thus "both dimensions are necessary in education and most particularly for learning" (Heugh, 2018, p. 360). Multilingual education that addresses both horizontal and vertical dimensions 
can build on students' existing capabilities, and develop new linguistic forms which grant access to powerful institutions (Stroud \& Heugh, 2004, p. 212).

In Australia, monolingual English texts and practices are highly valued in curriculum and assessment, and allow access to further education and social progression. EAL teaching within monolingually dominated Australian mainstream schools has a strong tradition of genre-based and systemic functional linguistics pedagogies (White, Mammone, \& Caldwell, 2015) for teaching the vertical elements of academic language across the curriculum. However, horizontal multilingual pedagogies that build on students' multilingual resources for identity construction, educational engagement, home language maintenance and English language learning (Sierens \& Van Avermaet, 2014) are yet to be comprehensively developed.

\section{Established multilingual pedagogies}

The monolingual mindset is apparent in Australian policy and curriculum that privilege monolingual constructions of English, including NAPLAN (National Assessment Program Literacy and Numeracy) (Schalley, Guillemin, \& Eisenchlas, 2015), the Australian Curriculum (Cross, 2012), and state curricula. However, as Lo Bianco recognises, despite these top-down influences, "teaching does provide a space of semi-autonomous activity" (2018, p. 24). At the level of classroom practice teachers have agency to shape the role of language in education from the bottom up (French, 2016; Heugh, 2018; Johnson, 2013) by implementing multilingual approaches in their planning and pedagogy.

Even where curriculum and institutional practice may be structured along monolingual lines, teachers can implement "functional multilingual learning" approaches which engage students' multilingual repertoires as resources for learning content and language (Sierens \& Van Avermaet, 2014, pp. 217-218). Cummins (2009) and García (2009) identify that multilingual learning requires explicit teaching for transfer of knowledge and skills from one language to another. Additionally, cognitive challenge combined with contextual and linguistic scaffolding supports content and language learning (Cummins, 1996, pp. 57-60). Most of all though, for academic achievement, students must see themselves reflected in the content and language of the curriculum (Cummins, 1996, p. 147). In approaches such as these 
teachers do not need to share the same languages as their students (Sierens \& Van Avermaet, 2014, p. 218), but rather facilitate students to interact, think and create using their full multilingual repertoires. This also allows students of different proficiencies in home language to engage with multilingual learning (Duarte, 2019).

Research and practice have established multilingual pedagogies, including discrete strategies addressing participation, content and language learning, and extended units of work. Although these approaches do not require teachers to know and use students' languages (Sierens \& Van Avermaet, 2014), there are other challenges in implementing multilingual pedagogies. The reproduction of the monolingual mindset in teacher education and curriculum design may limit teachers' skills and confidence in initiating multilingual pedagogies (Coleman, 2012). Further, centring learning around student languages and experiences entails a high degree of student agency, requiring teachers to relinquish traditional expectations of classroom control (Slembrouck, Van Avermaet, \& Van Gorp, 2018, p. 19).

\section{Participation}

Engaging multilingual repertoires in peer interaction demonstrably supports classroom participation. Research from Chau (2007) and Alby and Léglise (2018) shows that through home language use, students form stronger relationships, manage classroom activities and solve problems collaboratively. To enable this, teachers can group students with shared languages together (Chau, 2007; Goldstein, 2003) and explicitly support home language use in collaborative activities (Goldstein, 2003; Mohanty et al., 2010). Teachers can also engage students as classroom experts (Hardman, 1999), inviting them to co-teach, translate, translanguage, or present in home language (García, Flores, \& Woodley, 2012).

\section{Content learning}

Drawing content from students' diverse knowledges and experiences helps students connect to new learning and positions them as experts (Schwinge, 2003; Skilton-Sylvester, 2003). Written materials which support content learning may be available commercially or can be prepared by students or teachers. Bilingual dictionaries, text books and teaching materials in languages the students can read are valuable resources, supplementing standard 
texts and providing a range of cultural contexts for classroom content (García, Flores, \& Woodley, 2012; Mohanty, Panda, \& Pal, 2010; Schwinge, 2003).

\section{Language and literacy}

Multilingual pedagogies can support English language development. Multilingual interaction helps students translate vocabulary, check comprehension and formulate English sentences (Chau, 2007; de Jong \& Freeman Field, 2010). Transfer of linguistic knowledge can be taught through comparison of expression and meanings across languages, modelling experimentation with different languages (García, Flores, \& Woodley, 2012), and asking students to teach aspects of their language (Skilton-Sylvester, 2003). Home language reading and writing contribute to language and literacy skills across the multilingual repertoire. Teachers can provide home language realia and books to engage students in reading (Schwinge, 2003). Skills in using written script are transferable, so practicing home language writing is also valuable (Skilton-Sylvester, 2003). Translanguaging strategies in creating written texts include gathering information, writing outlines and drafts and reviewing English writing (Li et al., 2016). Students can create translanguaging texts, as in Schwinge's (2003) example of home language speech bubbles alongside English language stories. Additionally, students can share feedback and explain corrections multilingually in peer drafting activities (de Jong \& Freeman Field, 2010; Hardman, 1999).

\section{Integrated approaches}

Integrated approaches have also been developed which incorporate students' language practices over a longer course of study. Preview-view-review is a content learning strategy adapted from bilingual teaching. Firstly, students preview new concepts through collaboration with language peers and accessing home language materials which are "commercially made, teacher-made, student-made, or found on the internet" (de Jong \& Freeman Field, 2010, p. 115). In viewing, the teacher leads English language activities to develop knowledge further. Finally, in reviewing, students work with language peers "to reinforce and extend their learning in L1 [first language]" (de Jong \& Freeman Field, 2010, p. 115), through multilingual discussion, written summaries or quizzes. 
Identity texts use student experience as a basis and home languages as a medium for creating stories (Chow \& Cummins, 2003; Cummins, 2007; Cummins et al., 2006). Elements include eliciting stories that the students want to tell; working collaboratively to express these stories through home language; teacher scaffolding of appropriate school language to accompany the home language text; and sharing published texts with an authentic audience (Cummins, 2006).

Language awareness programs encourage cultural and linguistic understanding in diverse communities. In a French primary school, parents were invited into the school each week to share their linguistic and cultural knowledge, with this content subsequently incorporated into the class curriculum (Hélot \& Young, 2002). A video resource, Yo dude, cosa wena kyk a?: The Multilingual Classroom (Achmat, 1992) shows the teacher facilitating student-led lessons in a South African primary school. Language awareness programs combat stereotypes and increase engagement in school by both students and parents.

Another approach is linguistic ethnography such as the projects implemented by D'warte (2015) in Australian schools. Students explored their own multilingual repertoires, analysed multilingual practices of the class, and created visual representations of their linguistic practices in different contexts. This work connected to outcomes in the NSW syllabus and Australian Curriculum for English related to communicating effectively, and discussing how language is used (D'warte, 2014, p. 24).

A range of discrete classroom strategies or integrated units of work have been developed in diverse contexts to engage students' multilingual resources in learning (Heugh et al., 2019). These approaches are shown to support students' active participation, learning of subject content and development of multilingualism and English language. However, additional guidance may still be required for teachers to effectively develop these strategies into a connected multilingual pedagogy that addresses the complex demands of linguistically heterogeneous classes in Australian schools. Examples from one secondary school suggest principles for designing and implementing effective multilingual pedagogies in EAL and other curriculum areas. 


\section{Situated multilingual pedagogies}

Ethnographic study

This section describes multilingual approaches to learning in a culturally and linguistically diverse mainstream high school. Charity College ${ }^{1}$ is a suburban Catholic girls' secondary school in Adelaide, South Australia. At the time of the study, 48 percent of the 600 students spoke English in addition to their home language, with Dari, Vietnamese, Farsi, Dinka and Arabic the most widespread of 42 home languages. Approximately one third of students were EAL learners, including students with refugee experience, migrants and international students. EAL classes were taught each year level, with South Australian Certificate of Education (SACE) subjects at Years 11 and 12, including both an academic English language course and a general English language course in Year 12.

As an EAL teacher at the school, I observed students applying sophisticated multilingual skills in socialising and learning. However, multilingualism was often considered a deficit, as is the case in many Australian schools (Gearon, Miller, \& Kostogriz, 2009), and this disparity motivated the research. An ethnographic case study drew on multiple data sources including samples of work from 19 multilingual students, and focus group discussions involving 17 students. A questionnaire was completed by 35 staff, ten of whom also volunteered for individual interviews.

The data were analysed using a Grounded Theory approach (Glaser \& Strauss, 1967), with iterative readings of artefacts, transcripts and questionnaire responses drawing out "important, new, and persistent patterns" from student and staff data (Yin, 2010 , p. 219). It emerged that students employed multilingual resources and engaged translanguaging practices in socialising inside and outside school. For learning, students applied their multilingual resources individually, including translation of vocabulary and concepts, strategies to consolidate and transfer knowledge, and multilingual writing strategies. Collaboration was also an important domain of multilingual academic practice, and students used shared linguistic resources to support their peers and seek help. They did this through home languages and lingua francas such as Urdu, Hindi or Cantonese. Students also used multilingual capabilities to access external sources of information including internet sources, print media and members of language communities. These patterns of how students employed multilingual resources and engaged translanguaging practices are represented in Figure 1.

1 The school name and participant names are pseudonyms 


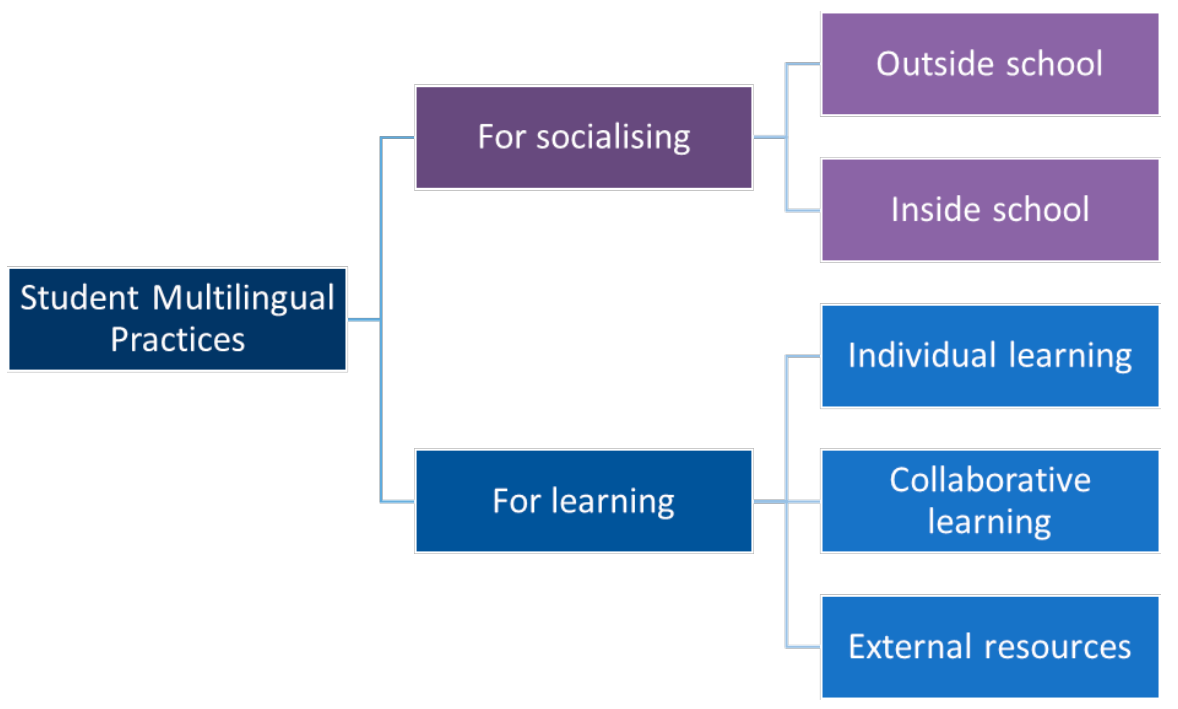

Figure 1: Students' multilingual practices

Within the monolingual structure of the school, these multilingual students demonstrated resourcefulness and agency in strategically applying their multilingual resources to achieve social and academic goals.

The teachers at Charity College responded in diverse ways to students' multilingual practices, which can be summarised on a continuum of practice (Figure 2). At one end of this is the position of rejection, in which multilingual practices were perceived as an obstacle to learning or inappropriate behaviour. Next is acceptance of students' multilingual practice, in which teachers valued multilingualism as a personal, social and academic resource, but felt they lacked the knowledge and expertise to apply this in the classroom. This was the most common position for teachers. At the other end of the continuum is the engagement of multilingual resources to support learning. In these rarer but varied cases, teachers incorporated student languages into classroom practice.

\section{Rejection > Acceptance > Engagement}

Figure 2: Continuum of teachers' responses to students' multilingual practices

This continuum represents situated practice rather than fixed ideologies of individual teachers. Teacher practices were varied and complex, and occupied different points along the 
continuum according to the situation. The agency of teachers was apparent as they attempted to balance students' multilingual resources against their understanding of dominant monolingual approaches to education.

The following section describes some multilingual approaches to learning taken from different stages of the research. One unit of work preceded and informed the research. From the ethnographic study come examples of multilingual learning strategies led by students and by teachers engaging students' multilingual resources. Continuing to work as an EAL teacher enabled me to build on the research by collaborating with colleagues to trial multilingual pedagogies. Units of work developed in response to the findings are also presented. Some principles for design and implementation of multilingual approaches are then drawn from these experiences and examples.

\section{Preceding unit}

An action research project in 2009 produced a one-term unit of work for Year $10 \mathrm{EAL}$, entitled Language, Literacy and Identity. The unit includes a linguistic ethnography project in which students "research language use in their school or community, gathering data through primary research methods" (French \& de Courcy, 2016, p. 256). Students also explore the connections between their multilingual practices, identities and learning through tasks including investigating the story behind their names, mapping language practices, identifying personal literacy identities and surveying the class about literacy resources. Successive years of teaching this unit highlighted the value of centralising multilingual students' expertise in the curriculum, and precipitated the study.

\section{Student-led strategies}

Examples of students employing multilingual resources for individual learning, collaboration and accessing external sources of information come from students completing the Research Project, a compulsory individual project for Year 12 students in the SACE.

In researching the experiences of Hazara people, Fatimah used online articles and books written in English, and "In addition, I also watch some Pakistani and other countries news report programs." ${ }^{2}$ Fatimah found particular value in interviewing community members in Urdu and Hazaragi. She reflected, "The

2 Quotations from participants are presented verbatim, without the use of 'sic,' in order to retain each individual's voice. 
Interviews were reliable and better evidence than the other sources. The interviews also gave me opportunity to compare the two interviews conducted, to gathered a different perspective and a wider range of knowledge about the research."

Angel, of Rwandan background, wrote about the skills in researching from a book written in Kinyarwanda.

The book what I have already was written in Kinyarwanda and I will translate in Swahili and English and this will help me in the future with the ability to read, write, spell, listen and speak. It will also help me in future to communicate with my friend and family in both of my languages and will help me be getting better in literacy.

Angel demonstrated resourcefulness in her use of technology. Because Kinyarwanda was not available on Google Translate, she first mentally translated her Kinyarwanda readings into Kiswahili. Next, she typed Kiswahili into the translation engine, to produce a rough translation in English, which she then rewrote using more appropriate English expression.

Fatimah and Angel's multilingual research processes allowed them to introduce valuable and otherwise hidden information into the school space. The students were highly resourceful, and the examples demonstrate that students can effectively conceive of, implement and evaluate multilingual learning strategies, with the teacher playing a facilitative role.

\section{Teacher-led strategies}

Although in many cases, acceptance of students' multilingualism was accompanied by teachers' uncertainty about multilingual pedagogies, interviews revealed that teachers sometimes engaged students' multilingual practices in innovative ways in diverse subjects. Judy, teaching Design, observed students working in Hazaragi to generate ideas. She reported, "When asked to write their responses in English, they could only express one to two points. When asked to write their responses in their own language, they came up with an additional four points." When Judy encouraged her class to try this technique, however, most students declined because, she believed, "the girls didn't want to feel 'different' to everyone else."

Drama teacher Steve recounted the performance of a Dinka speaking student, Victoria. "She took Oberon's part and I translated it [from Shakespearean] into English. And then she translated that into Dinka, and then she said it in Dinka." Steve 
perceived difficulty assessing this task. "Well the problem is, at the end of the day, we assess in English. What else can you do?" However, he considered her performance a success, as "She performed that role in a way she could never have done. ... She went into the role rather than the role being forced on her."

Anita described her student's multilingual text analysis in a flexible learning class.

She has a son who's four so he's about to start school. ... [O]ne of the tasks is to do something, like a story book for a child.... And she's chosen a book that's got the text in English, in her language and a few other languages.

Anita saw positive outcomes from this project. "It's great that she's enjoying it ... he's benefiting from it too." The benefits of this task extended beyond the student to her family.

In an IT class, Dennis enabled different language options for software. However, he explained, it was not always practical to apply these features. "[I]t worked alright for some of the Vietnamese speaking kids at Charity, but you give it to the Persian speaking ones and they're like, 'Oh, we can't read Persian.'”

These cases demonstrate how teachers can move from a position of acceptance to one of engagement by recognising and responding to students' multilingual practices. The agency of teachers is key in decision-making about whether and how to implement multilingual strategies. These examples also highlight some considerations for successful multilingual pedagogies, such as affective aspects, academic and social outcomes, and practical considerations.

\section{Multilingual units}

Building on the findings of the ethnographic study, I collaborated with other EAL teachers at Charity College to adapt existing tasks and develop new multilingual approaches. Tasks were designed so students could engage at different levels of home language proficiency and literacy, including undertaking tasks solely through English. Table 1 summarises the main multilingual tasks for each EAL class. Folk Tales, Translation Study and Linguistic Landscape will be described in more detail. Table 1: Multilingual tasks in EAL curriculum at Charity College. 


\begin{tabular}{|c|c|}
\hline Subject & Tasks \\
\hline Year 8 EAL & $\begin{array}{l}\text { Translation study: students analyse and improve a } \\
\text { short passage translated from their home language } \\
\text { to English, and reflect on the process. } \\
\text { Folk tales: students listen to a story told in home } \\
\text { language, and rewrite and/or record audio for a } \\
\text { home language and English version. }\end{array}$ \\
\hline Year 9 EAL & $\begin{array}{l}\text { Class recipe book: students cook a dish at home } \\
\text { and write a recipe in English. Model texts include } \\
\text { recipes in unfamiliar languages. }\end{array}$ \\
\hline Year 10 EAL & $\begin{array}{l}\text { Language, Literacy } \mathcal{E}^{2} \text { Identity } \\
\text { Folio: students record, share and reflect on their } \\
\text { different language practices. } \\
\text { Language research: students investigate language } \\
\text { use in their life and make a multimodal } \\
\text { presentation of research question, method, } \\
\text { findings and analysis. }\end{array}$ \\
\hline $\begin{array}{l}\text { Year } 11 \text { EAL } \\
\text { (SACE Stage } 1 \text { EAL) }\end{array}$ & $\begin{array}{l}\text { Song analysis: students analyse and compare } \\
\text { poetic techniques in song lyrics in two languages. } \\
\text { Translation study (as above) }\end{array}$ \\
\hline $\begin{array}{l}\text { Year } 12 \text { Essential } \\
\text { EAL } \\
\text { (SACE Stage } 2 \\
\text { Essential English: } \\
\text { general English) }\end{array}$ & $\begin{array}{l}\text { Social media analysis: students describe and } \\
\text { analyse the way they translanguage and use } \\
\text { multiple languages in their social media } \\
\text { interactions. } \\
\text { Linguistic landscape: students analyse linguistic } \\
\text { features and social implications of languages } \\
\text { visible in a public place. }\end{array}$ \\
\hline $\begin{array}{l}\text { Year } 12 \text { EAL } \\
\text { (SACE Stage } 2 \text { EAL: } \\
\text { academic English) }\end{array}$ & $\begin{array}{l}\text { Translation study (as above) } \\
\text { Research tasks: students may incorporate } \\
\text { information from home language books, websites, } \\
\text { videos, news media and interviews. }\end{array}$ \\
\hline
\end{tabular}

\section{Folk Tales}

A long-standing task, Folk Tales in Year 8 EAL was adapted to explicitly incorporate students' multilingual practices of oral storytelling and accessing stories online. When writing their own tale, students can create a multilingual or English-only text. In Figure 3, the student has used English, transliterated Dari, Persian script and an illustration to tell her story. 


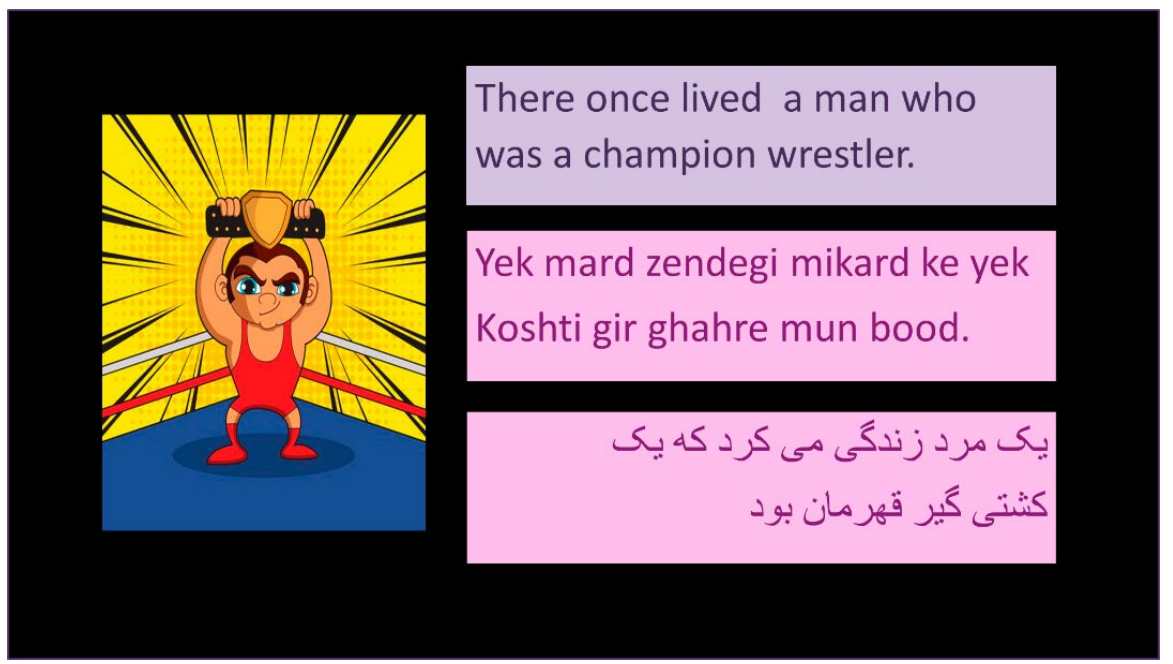

Figure 3: Student work from Year 8 EAL Folk Tales unit (French, 2018).

The student reported that her writing process involved:

- Listening to her father telling the story in Persian

- Translating the story mentally into English

- Avoiding word-for-word translation, writing an appropriate English version

- Retelling the story to her father in Persian, and editing according to his feedback

This student's work contained appropriate translation as well as conventions of folk tales in both languages, for example the English phrase "There once lived." The apparent simplicity of the student's finished text belies her complex multilingual process. Additionally, the collaborative nature of this approach presented a rare opportunity to engage EAL students' family members in curriculum activities.

\section{Translation Study}

Teachers created Translation Study to explicitly build on students' experiences as language brokers (Morales \& Hanson, 2005) and further develop skills in translating. Students find or generate a short translated text, compare the language features of the home language and English texts, develop an alternative translation, and reflect on translation as a multilingual and translanguaging process. This task has been adapted to Year 8, Year 11 and Year 12 levels. Figure 4 is a sophisticated excerpt from a Year 12 student, while Figure 5 presents a simpler Year 8 text. 
Analysis of the translation process exposed

minor inaccuracies. As a result of the

vocabulary differences, the true meaning of

the song was not conveyed. For example, the

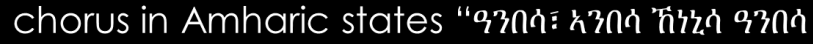

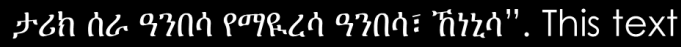

incorporated figurative language to imply that

Kenenisa is the greatest of all time. However,

the English version fails to comprehend the

singer's message when it refers to "the lion,

that can never be forgotten", instead of

explaining Kenenisa's great accomplishments.

Therefore, the complexity of the English

language does not hold the same cultural

references.

Figure 4: Student work from Year 12 EAL Translation Study unit (French, 2018).

In Figure 4, the student incorporates two languages in her critique of the original Amharic text and its English translation.

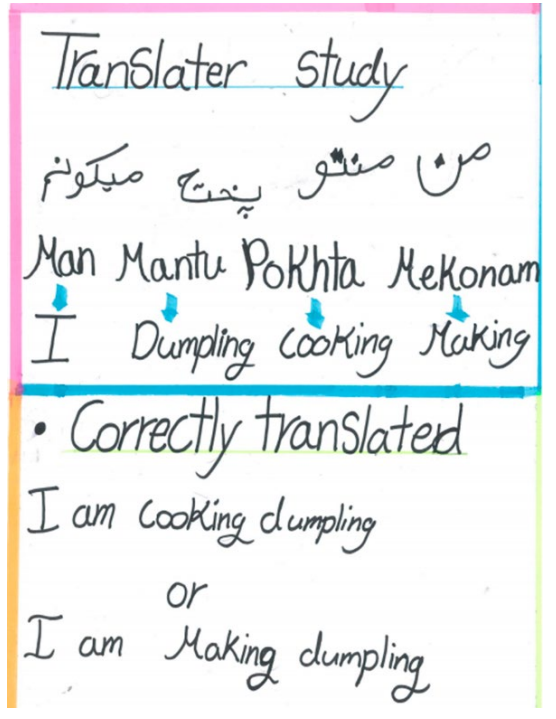

Figure 5: Student work from Year 8 EAL Translation Study unit (French, 2018).

Although the task has been simplified for Year 8, it can be seen in Figure 5 that the student undertook complex translation processes, transforming the sentence in three different ways: 
- Transliteration, writing the Dari sounds out using English script

- Word-for-word translation, retaining Dari word order with English vocabulary

- Adapted translation (Heugh, Li, \& Song, 2017, p. 266), rewriting the sentence with appropriate English expression

Teachers found that the Translation Study effectively engaged students in collaboration, high level analysis, and reflection on linguistic and cognitive processes.

\section{Linguistic Landscape}

In the Linguistic Landscape unit, Year 12 students are oriented to concepts of linguistic landscape (Landry \& Bourhis, 1997) through an excursion to multicultural shopping areas. Following this, students individually examine a chosen linguistic landscape, analysing linguistic, cultural and social aspects. In the excerpt in Figure 6 the student has discussed the language and design of multilingual signs, and how these impact particular people.

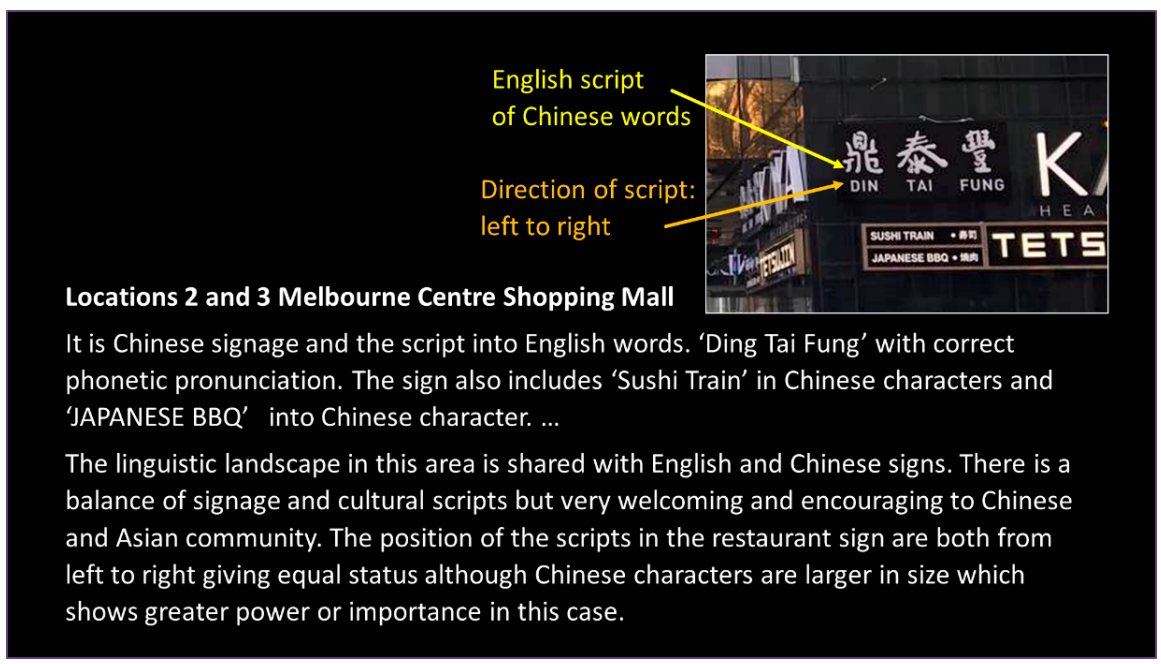

Figure 6: Student work from Year 12 Essential EAL Linguistic Landscape unit (French, 2018).

The Linguistic Landscape task is submitted for SACE external assessment, meaning it is centrally marked and constitutes 30 percent of students' final subject grades. In this way, the multilingual practice of these Year 12 students is not confined to the classroom, but is made visible at the state level of curriculum and assessment. 
These examples illustrate approaches derived from the multilingual practices of students at Charity College. There are discrete learning strategies implemented by multilingual students or developed by teachers. Building on these are extended tasks that engage students' multilingual resources and translanguaging practices in the process of learning, as content for analysis and in some cases in texts produced for assessment. Designed to engage sociolinguistic and metalinguistic skills, the tasks engage students at different levels of home language proficiency and literacy. Teachers do not need to know their students' languages, as their role is to facilitate horizontal multilingual learning strategies and teach academic skills and language connected to vertically structured hierarchies of English.

\section{Designing multilingual pedagogies}

These examples of multilingual learning and teaching can serve as a basis for distilling key considerations for effective multilingual pedagogies, particularly in relation to students' roles and factors in task design. Although they arise out of the specific context of Charity College, these principles might be adapted to other linguistically diverse contexts.

\section{Student input}

Just as effective content and language learning builds on students' prior knowledge, the study suggests that multilingual strategies and tasks should build on the existing multilingual practices of students. At Charity College, students have developed a foundation of practice and expertise in applying sociolinguistic, metalinguistic and linguistic skills to individual and collaborative learning, which can form the basis for content and process in multilingual tasks.

The study demonstrated the agency of Charity College students in their strategic use of multilingual resources to support social and academic outcomes. Students exercise agency in generating multilingual approaches to learning, and in accepting or rejecting multilingual strategies devised by teachers. Within multilingual tasks, students can determine how and to what extent they will apply their multilingual resources, according to their home language proficiency, multilingual skill set and aspirations for developing their multilingual and English language capabilities. This suggests that task design should allow degrees of choice over topics and texts in order to make most effective use of multilingual 
repertoires, and support opportunities to flexibly apply multilingual resources in individual and collaborative activities.

The expertise and agency of multilingual students suggests that it is not only teachers who impact on multilingual learning at the classroom level. Although the role of students is often absent from analysis of language in educational policy and curriculum (Johnson, 2013, p. 99), it is apparent that multilingual students at Charity College exert strong agency in their use of languages for learning. The multilingual practice initiated by students, developed through collaboration with peers, supported by teachers and made visible even in state curriculum and assessment, has the potential to enliven educational practice.

\section{Teacher input}

Although teachers may need to relinquish some aspects of control in multilingual approaches (Slembrouck, Van Avermaet, \& Van Gorp, 2018, p. 19), the expertise of teachers is vital in planning and managing learning, in supporting students to apply multilingual strategies at suitable times and in productive ways, and in teaching English language texts and forms (French \& Armitage, forthcoming). This requires teachers to account for vertical and horizontal multilingualism and a range of additional factors that support successful multilingual task design and teaching.

The roles of vertical and horizontal dimensions of multilingualism are particularly evident in the EAL units of work. Into the senior secondary years, assessment requires more complex and formal English texts and expression. That is, students need to perform at higher levels in the vertical hierarchy of English language forms. Established TESOL pedagogies such as genre-based and functional approaches remain central to the teaching of highly valued English language texts. These approaches can be combined with pedagogies that support horizontal multilingualism in the processes and content of language learning.

Additional factors to consider in the design and implementation of multilingual pedagogies include affect, academic and social outcomes, and practicalities. Each of these considerations is illustrated in the examples of teacher-led multilingual learning. Accounting for affect entails consistently valuing students' multilingual repertoires and establishing regular opportunities to apply multilingual resources in classroom activities. Multilingual strategies should also support skills and 
learning that the student and teacher both value, whether these are related to assessment criteria, subject content and skills, or authentic social purposes in family and community contexts. Furthermore, practical factors including the prior knowledge and existing skills of students, along with the technology, time and skills available to the teacher, should all be considered in the design of multilingual pedagogies.

\section{Conclusion}

Education in Australia is founded on a "monolingual mindset" (Clyne, 2008) which prioritises monolingual English as both the medium and outcome. Nevertheless, teachers who take a multilingual stance can implement multilingual approaches which support students and may influence higher levels of the curriculum. EAL specialists are well placed to design and implement pedagogies which engage both vertical and horizontal dimensions of multilingualism. Established EAL approaches are effective in advancing learning of vertically structured powerful forms of English, which are often assessed as the products of learning.

In the horizontal dimension, multilingual practices can be incorporated as content for analysis, and in the processes of learning. The practices of students and the experiences of teachers at Charity College suggest principles for the design and implementation of successful multilingual pedagogies. The first principle is to understand students' existing multilingual practices and use these as the basis for task design and classroom strategies. Tasks should be designed with flexibility to allow students to make choices about how and to what extent they apply their multilingual resources to learning. Multilingual pedagogies should also address factors including affective aspects, learning and social outcomes, and practical considerations in teaching. However, it should also be noted that the distinction between vertical forms of language as products for assessment, and horizontal multilingual practices as learning processes, is not a strict one. With experience and creativity, teachers may be able to develop tasks and approaches that make horizontal multilingual practices more visible in assessment.

The expertise of EAL teachers shapes effective multilingual pedagogy. Even in institutions where monolingual practices prevail, Heugh recognises that "Promising change comes from below, from teachers in the classrooms" (2018, p. 356). Equally influential is the expertise and agency with which students apply 
their multilingual resources to learning. In initiating and developing multilingual approaches for the classroom, the practices of students help to challenge the monolingual mindset of Australian education.

\section{References}

Achmat, Z. (1992). 'Yo dude, cosa wena kyk, a?: The multilingual classroom'. Cape Town: The National Language Project. Retrieved from https://www.youtube.com/ watch? $v=$ rhzhq $46 \mathrm{gLCo}$

Alby, S., \& Léglise, I. (2018). 'Multilingualism and translanguaging as a resource for teaching and learning in French Guiana', in P. Van Avermaet et al. (Eds.), The multilingual edge of education. London: Palgrave Macmillan, pp. 115-137. doi:10.1057/978-1-137-54856-6_6

Busch, B. (2012). 'The linguistic repertoire revisited', Applied Linguistics, 33(5), pp. 503-523. doi:10.1093/applin/ams056

Chau, E. (2007). 'Learners' use of their first language in ESL classroom interactions', TESOL in Context, 16(2), pp. 11-18.

Chow, P., \& Cummins, J. (2003). 'Valuing multilingual and multicultural approaches to learning', in S. R. Schecter \& J. Cummins, (Eds.), Multilingual education in practice: Using diversity as a resource. Portsmouth: Heinemann, pp. 32-61.

Clyne, M. (2008). 'The monolingual mindset as an impediment to the development of plurilingual potential in Australia', Sociolinguistic Studies, 2(3), pp. 347-366.

Coleman, J. (2012). 'Moving beyond an "instrumental" role for the first languages of English language learners', TESOL in Context, 22(1), pp. 18-37.

Cross, R. (2012). 'Reclaiming the territory: Understanding the specialist knowledge of ESL education for literacy, curriculum and multilingual learners', TESOL in Context, 22(1), pp. 4-17.

Cummins, J. (1996). Negotiating identities: Education for empowerment in a diverse society. Ontario: California Association for Bilingual Education.

Cummins, J. (2006). 'Identity texts: The imaginative construction of self through multiliteracies pedagogy', in O. García, T. Skutnabb-Kangas, \& M. E. Torres-Guzman (Eds.), Imagining 
Multilingual Schools: Language in Education and Globalization. Clevedon: Multilingual Matters, pp. 51-68.

Cummins, J., Bismilla, V., Cohen, S., Giampapa, F., \& Leoni, L. (2006). 'Timelines and lifelines: Rethinking literacy instruction in multilingual classrooms', Orbit, 36(1), pp. 22-26.

Cummins, J. (2007). 'Rethinking monolingual instructional strategies in multilingual classrooms', Canadian Journal of Applied Linguistics/Revue Canadienne de Linguistique Appliquee, 10(2), pp. 221-241. Retrieved from http://ojs.vre. upei.ca/ index.php/cjal/article/viewArticle/267 (Accessed: 6 October 2012).

Cummins, J. (2008). 'Teaching for transfer: Challenging the two solitudes assumption in bilingual education', in J. Cummins \& N. H. Hornberger (Eds.), Encyclopedia of Language and Education, Volume 5: Bilingual Education. (2 ${ }^{\text {nd }}$ edn.). New York: Springer, pp. 65-75. doi:10.1007/978-0-387-304243_116

Cummins, J. (2009). 'Fundamental psycholinguistic and sociological principles underlying educational success for linguistic minority students', in T. Skutnabb-Kangas et al. (Eds.), Social Justice Through Multilingual Education. Clevedon: Channel View Publications, pp. 19-35.

D’warte, J. (2014). 'Exploring linguistic repertoires: Multiple language use and multimodal literacy activities in five classrooms', Australian Journal of Language and Literacy, 37(1), pp. 21-30.

D'warte, J. (2015). 'Building knowledge about and with students: Linguistic ethnography in two secondary school classrooms', English in Australia, 50(1), pp. 39-48.

de Jong, E. J., \& Freeman Field, R. (2010). 'Bilingual approaches', in C. Leung \& A. Creese (Eds.), English as an Additional Language: Approaches to Teaching Linguistic Minority Students. London: Sage, pp. 108-121.

Duarte, J. (2019). Translanguaging in mainstream education: A sociocultural approach. International Journal of Bilingual Education and Bilingualism, 22(2), 150-164. doi:10.1080/136 70050.2016 .1231774

French, M. (2016). 'Students' multilingual resources and policy-inaction: An Australian case study', Language and Education. 
Taylor \& Francis, 30(4), pp. 298-316. doi:10.1080/09500782 .2015 .1114628

French, M. (2018). 'Multilingual and translanguaging pedagogies in EALD'. Melbourne: Languages and Multicultural Education Resource Centre (LMERC), p. 2018. Retrieved from https://fuse.education.vic.gov.au/Resource/ LandingPage?ObjectId $=0 \mathrm{ac}$

French, M., \& Armitage, J. (forthcoming). 'Eroding the monolingual monolith', Australian Journal of Applied Linguistics.

French, M., \& de Courcy, M. (2016). 'A place for students' Multilingual resources in an Australian high school', in C. Snowden \& S. Nichols (Eds.), Languages and Literacies as Mobile and Placed Resources. Oxon: Routledge, pp. 153-169.

García, O. (2009). Bilingual Education in the 21st Century: A Global Perspective. Chichester: Wiley Blackwell. doi:10.1080/014346 32.2010 .515718

García, O., Flores, N., \& Woodley, H. H. (2012). 'Transgressing monolingual and bilingual dualities: Translanguaging pedagogies', in A. Yiakometti (Ed.), Rethinking Education, Volume 5: Harnessing Linguistic Variation to Improve Education. Oxford: Peter Lang AG. doi:10.1017/ CBO9781107415324.004

Gearon, M., Miller, J., \& Kostogriz, A. (2009). 'The challenges of diversity in language education', in J. Miller, A. Kostogriz, \& M. Gearon (Eds.), Culturally and Linguistically Diverse Classrooms. New Dilemmas for Teachers. Bristol: Multilingual Matters, pp. 3-17.

Glaser, B. G., \& Strauss, A. L. (1967). The Discovery of Grounded Theory: Strategies for Qualitative Research. New Brunswick: Aldine Transaction.

Goldstein, T. (2003). 'Contemporary bilingual life at a Canadian high school: Choices, risks, tensions, and dilemmas', Sociology of Education, 76(3), pp. 247-264.

Hardman, J. C. (1999). 'A community of learners: Cambodians in an adult ESL classroom', Language Teaching Research, 3(2), pp. 145-166. doi:10.1177/136216889900300204.

Hélot, C., \& Young, A. (2002). 'Bilingualism and language education in French primary schools: Why and how should migrant languages be valued ?', International Journal Of Bilingual Education And Bilingualism, 5(2), pp. 96-112. 
Heugh, K. (2015). 'Epistemologies in multilingual education: Translanguaging and genre - companions in conversation with policy and practice', Language and Education, 29(3), pp. 280-285. doi:10.1080/09500782.2014.994529

Heugh, K. (2018). 'Conclusion: Multilingualism, diversity and equitable learning: Towards crossing the "abyss"', in P. Van Avermaet et al. (Eds.), The Multilingual Edge of Education. London: Palgrave Macmillan, pp. 341-367. doi:10.1057/9781-137-54856-6_15.

Heugh, K. (2019). 'Language contact and languaging', in Z. Bock, Z. (Ed.), Language, Society and Communication: An Introduction. ( $2^{\text {nd }}$ ed.). Pretoria: Van Schaik Publishers, pp. 369-400.

Heugh, K., French, M., Armitage, J., Taylor-Leech, K., Billinghurst, N., \& Ollerhead, S. (2019). Using Multilingual Approaches: Moving from Theory to Practice. London: British Council. Retrieved from https://www.teachingenglish.org.uk/sites/ teacheng/files/Using_multilingual_approaches.pdf

Heugh, K., Li, X., \& Song, Y. (2017). 'Multilingualism and translanguaging in the teaching of and through English: Rethinking linguistic boundaries in an Australian university', in B. Fenton-Smith, P. Humphreys, \& I. Walkinshaw (Eds.), English Medium Instruction in Higher Education in Asia-Pacific. Netherlands: Springer, pp. 259-279. doi:10.1007/978-3-31951976-0

Johnson, D. C. (2013). Language Policy. London: Palgrave Macmillan. doi:10.1057/9781137316202

Landry, R., \& Bourhis, R. Y. (1997). 'Linguistic landscape and ethnolinguistic vitality: An empirical study', Journal of Language and Social Psychology, 16(1), pp. 23-49. doi: https:/ / doi.org/10.1177/0261927X970161002

Li, X., Heugh, K., O’Neill, F., Scarino, A., \& Crichton, J. (2016). 'Developing English language and intercultural learning capabilities: An investigation in the Division of Education, Art and Social Science'. Research Centre for Languages and Cultures, University of South Australia.

Lo Bianco, J. (2018). 'Provision, policy and reasoning: The pluralisation of the language education endeavour', in J. Choi, \& S. Ollerhead (Eds.), Plurililingualism in Teaching and Learning. New York: Routledge, pp. 21-35.

May, S. (2011). 'Language policy', in M. Grenfell (Ed.), Bourdieu, Language and Linguistics. London: Continuum, pp. 147-169. 
Mohanty, A., Panda, M., \& Pal, R. (2010). 'Language policy in education and classroom practices in India', Negotiating Language Policies in Schools: Educators as Policymakers, pp. 211-231.

Morales, A., \& Hanson, W. E. (2005). 'Language brokering: An integrative review of the literature', Hispanic Journal of Behavioral Sciences, 27(4), pp. 471-503. doi:10.1177/0739986305281333

Ollerhead, S., Choi, J., \& French, M. (2018). 'Introduction', in J. Choi \& S. Ollerhead (Eds.), Plurililingualism in Teaching and Learning. New York: Routledge, pp. 1-18.

Saxena, M., \& Martin-Jones, M. (2013). 'Multilingual resources in classroom interaction: Ethnographic and discourse analytic perspectives', Language and Education, 27(4), pp. 285-297. doi:10.1080/09500782.2013.788020

Schalley, A. C., Guillemin, D., \& Eisenchlas, S. A. (2015). 'Multilingualism and assimilationism in Australia's literacyrelated educational policies', International Journal of Multilingualism, 12(2), pp. 162-177. doi:10.1080/14790718.2 015.1009372

Schwinge, D. (2003). 'Enabling biliteracy: Using the continua of biliteracy to analyze curricular adaptations and elaborations', in N. H. Hornberger (Ed.), Continua of Biliteracy: An Ecological Framework for Educational Policy, Research, and Practice in Multilingual Settings. Clevedon: Multilingual Matters, pp. 278-295.

Sierens, S., \& Van Avermaet, P. (2014). 'Language diversity in education: Evolving from multilingual education to functional multilingual learning', in D. Little, C. Leung, \& P. Van Avermaet (Eds.), Managing Diversity in Education: Languages, Policies, Pedagogies. Bristol: Multilingual Matters, pp. 204-222.

Skilton-Sylvester, E. (2003). 'Legal discourse and decisions, teacher policymaking and the multilingual classroom: Constraining and supporting Khmer/English biliteracy in the United States', International Journal of Bilingual Education and Bilingualism, 6(3-4), pp. 168-184. doi:10.1080/13670050308667779

Slembrouck, S., \& Rosiers, K. (2018). 'Translanguaging: A matter of sociolinguistics, pedagogics and interaction?', in P. Van Avermaet et al. (Eds.), The Multilingual Edge of Education. 
London: Palgrave Macmillan, pp. 165-187. doi:10.1057/9781-137-54856-6_8

Slembrouck, S., Van Avermaet, P., \& Van Gorp, K. (2018). 'Strategies of multilingualism in education for minority children', in P. Van Avermaet et al. (Eds.), The Multilingual Edge of Education. London: Palgrave Macmillan, pp. 9-39.

Stroud, C., \& Heugh, K. (2004). 'Language rights and linguistic citizenship', in J. Freeland \& D. Patrick (Eds.), Language Rights and Language Survival: Sociolinguistic and Sociocultural Perspectives. Manchester: St Jerome, pp. 191-218.

White, P. R. R., Mammone, G., \& Caldwell, D. (2015). 'Linguistically based inequality, multilingual education and a genre-based literacy development pedagogy: Insights from the Australian experience', Language and Education. Taylor \& Francis, 29(3), pp. 256-271. doi:10.1080/09500782.2014.994527

Yin, R. K. (2010). Qualitative Research from Start to Finish. New York: The Guilford Press.

Dr Mei French has worked as an EAL teacher in Australian high schools and is an academic researcher with the University of South Australia. She has particular expertise in curriculum and pedagogies which build on students' multilingual repertoires. Through these pedagogies, students build strong connections to language learning and broader curriculum. Mei's PhD investigated the complex and purposeful multilingual practices, including translanguaging, of high school students and their teachers, and the implications for pedagogy and policy.

mei.french@mymail.unisa.edu.au 